\title{
Compliance on HACCP and export penetration: An empirical analysis of the seafood processing firms in Sri Lanka
}

\author{
D.A.M. De Silva ${ }^{1}$ and Masahiro Yamao ${ }^{2}$
}

1,2 Dept. of Food and Resource Economics, Graduate School of Biosphere Sciences, Hiroshima University, 1-4-4, Kagamiyama, Higashi Hiroshima, 739-8528, Japan.desilva.achini@yahoo.co.uk and yamao@hiroshima-u.ac.jp

\begin{abstract}
Seafood exporting enterprises have to produce to the requirements of their international markets and demonstrate acceptable conformity to food safety regulations. The basic purpose of this study was to investigate the present status of food safety programmes (HACCP) in seafood business in Sri Lanka and determine the food safety practices and procedures related to the HACCP. The principle focus was to find out the impact of HACCP, level of sanitation, labor, capital and traceability on export penetration of the seafood export business in Sri Lanka. A structured questionnaire was used to collect the primary data from purposely selected seafood processing establishments in Sri Lanka $(n=50)$. An analysis showed that $72 \%$ of the export penetration was described by the selected dependent variables. Moreover, findings highlighted that the level of HACCP observance, labor, capital, sanitation (SANI 1) and traceability have positive correlation with export penetration while poor sanitation (SANI 2) has a negative impact on export penetration.
\end{abstract}

Key words: seafood, exports of Sri Lanka, HACCP, compliance

\section{Introduction}

Sri Lankan fresh and processed marine food producers and shippers face continuously growing demands on quality, regarding both product and process attributes. The first ones concern attributes such as color, size, flavor, freshness, homogeneity and other intrinsic characteristics these can be directly observed on the marine products at all different stages of the production chain, from harvest to consumption (Sanchez, 2004). Process attributes cannot be observed after the specific production process is concluded; they include characteristics such as geographical origin, environment protection, hygiene and food safety (Sanchez, 2004). In economic literature, the first ones are defined as both search or experience attributes and the second ones as credence attributes (Codron et al., 2000). Companies in the fresh production chain have progressively established 
coordination mechanisms for quality management in order to achieve better adaptation between consumers' demands and producers' capacities (Sanchez, 2004). The companies can adopt specific, product oriented quality approaches (such as brands, product certifications and labels) or more generic management-oriented approaches (such as International Standards Organization/ISO 9000 and Hazard Analysis Critical Control Point/ HACCP). Given the short-life period of fresh fish, the high uncertainty of both supply and demand, and the difficulties of enforceable quality assessment along the distribution chain, specific quality approaches have shown limited applicability in the sector. Generic approaches have emerged as new alternatives to companies in the marine food sector in general (The United States Food and Drug Administration [USFDA] was the first to enforce the requirements of HACCP in 1997), and especially in the fresh fish exports industry. Implementation of HACCP system is a fundamental approach to ensure the safety of the food supply; it is a systematic procedure for the identification, evaluation and control of hazards in each food operation (Codron et al., 2000; Cato, 1998). The establishment of "quality control unit" in 1998 belongs to the Ministry of Fisheries and Aquatic Resources was the starting point of HACCP guided food Safety measures in Sri Lanka. Table l describes the number of seafood processing and export companies of Sri Lanka throughout the time line. Moreover, percentage share of fish and fishery products exports by sub-sectors is showing in figure $l$.

Table l: Seafood processing and export companies in Sri Lanka

\begin{tabular}{|l|c|c|c|c|}
\hline Product & 1990 & 1996 & 2002 & 2006 \\
\hline Ornamental fish & 59 & 54 & 91 & 92 \\
\hline Tuna & - & 8 & 24 & 39 \\
\hline Maldive fish and Substitutes & 31 & 73 & 81 & 93 \\
\hline Sprats and dried un salted fish & 4 & 51 & 59 & 64 \\
\hline Shark fins & - & 23 & 21 & 22 \\
\hline Fish maws & - & 2 & 8 & 10 \\
\hline Lobsters & 14 & 16 & 23 & 26 \\
\hline Shrimps and prawns & 36 & 45 & 45 & 46 \\
\hline Crabs & 15 & 9 & 44 & 47 \\
\hline Live edible fish & - & - & - & 11 \\
\hline Sea weed & - & - & - & 03 \\
\hline Seafood and others & - & - & - & 23 \\
\hline Total & 159 & 281 & 396 & 476 \\
\hline
\end{tabular}

Source: Department of Customs, Sri Lanka, 1990-2006 


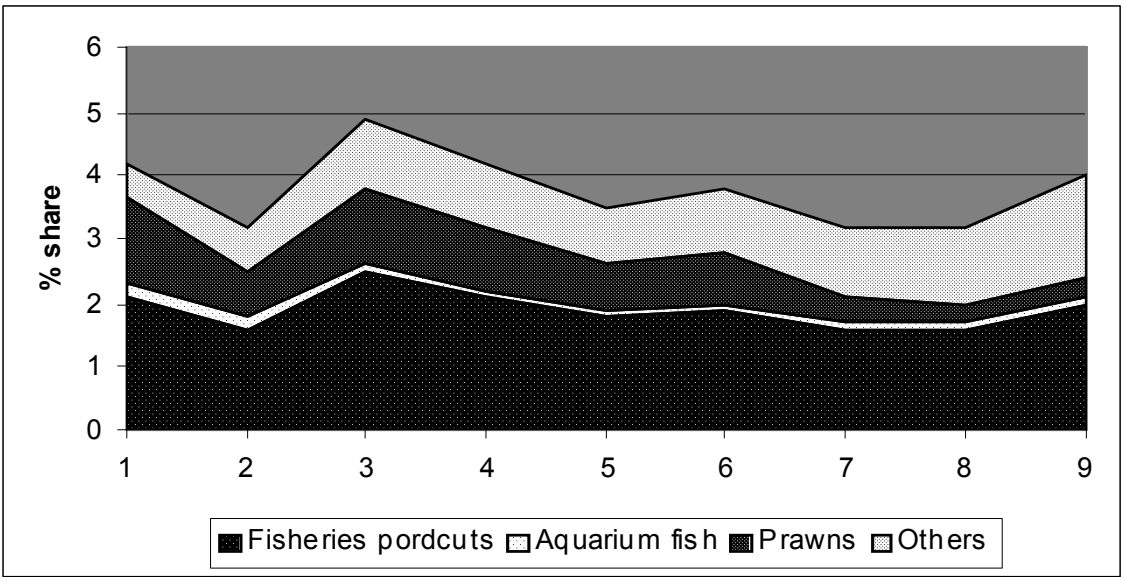

Figure 1: Share (\%) of fish and fishery products exports by sub-sectors in Sri Lanka

Source: Department of Customs, Sri Lanka, 2003

The higher value markets in the European Union (EU and United States of America (USA) have triggered the need for production under the HACCP system in most fish exporting countries. In the current situation, approximately $60 \%$ (volume basis) of the international fish markets require that fish and fishery products be processed under HACCP systems (Lupin, 1999). Japan is the only large fish market (around 34\% of the volume traded) that has not yet requested HACCP compliance (Lupin, 1999; Martins, 1993). Figure 2 shows the trend of main seafood product categories exported from Sri Lanka.

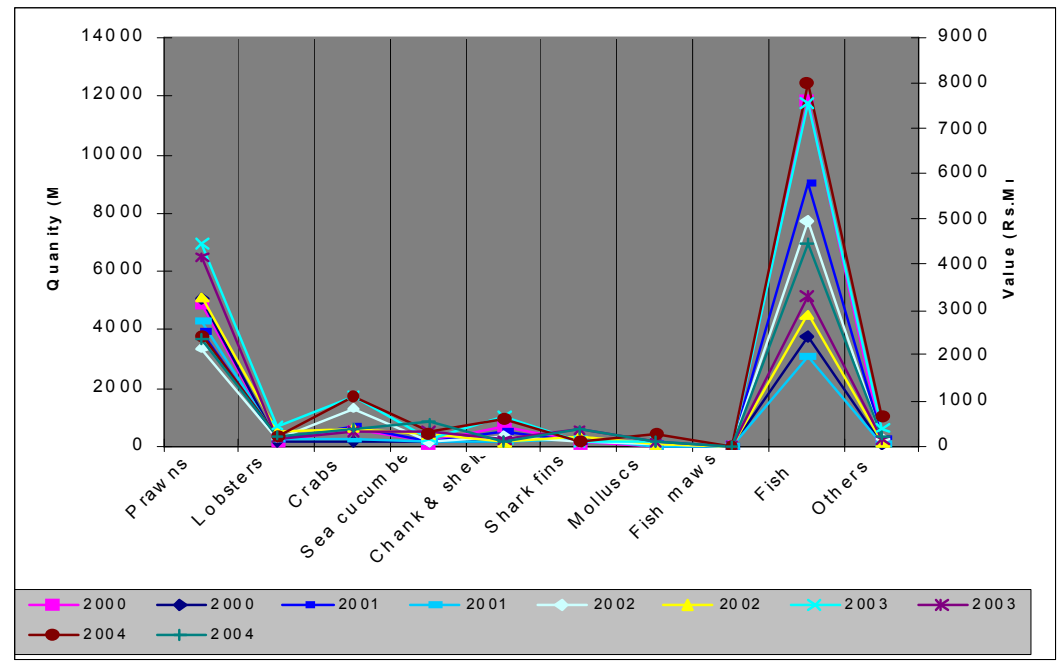

Figure 2: Quantity and Value of fish and fish products exports, 1998-2001

Source: Export Development Board (EDB) annual reports, 1998-2003 
It is of great importance that Sri Lanka develops its seafood export market, which is seen as one of the most attractive sectors for a traditional agricultural economy. Marine products become an important, hard currency earner, surpassing other traditional agricultural economies while absorbing growing the labor force in fishing communities. Fishing and fish production are vital to the Sri Lankan economy, and over 100,000 people depend on the industry for their livelihood. At present, Sri Lanka exports fish products to many destinations, mainly to Japan, the USA and the EU. Table 2 shows the percentage of seafood exports to major markets. Statistics for the year 2003 revealed that the fishing industry contributed 3\% to the GNP (Central Bank of Sri Lanka, 2003). Furthermore, table 2 shows the export market destinations for Sri Lankan seafood exports.

Table 2: Trends of seafood export markets of Sri Lanka (selected fish and fish products)

\begin{tabular}{|l|c|c|c|c|c|c|c|}
\hline \multirow{2}{*}{ Description } & \multicolumn{7}{|c|}{ Year } \\
\cline { 2 - 9 } & 1990 & 1992 & 1994 & 1996 & 1998 & 2000 & 2002 \\
\hline Ornamental fish & 32 & 29 & 41 & 50 & 54 & 54 & 50 \\
\hline Yellow fin Tuna & - & 1 & 2 & 7 & 8 & 14 & 18 \\
\hline Maldive fish and substitutes & 7 & 16 & 18 & 33 & 26 & 27 & 29 \\
\hline Sprats and dried fish & 3 & 6 & 12 & 26 & 20 & 23 & 22 \\
\hline Shark fins & - & - & - & 5 & 6 & 6 & 6 \\
\hline Fish Maws & - & - & - & 1 & 2 & 2 & 4 \\
\hline Lobsters & 9 & 9 & 9 & 8 & 3 & 7 & 10 \\
\hline Shrimp and Prawn & 18 & 14 & 21 & 22 & 16 & 21 & 13 \\
\hline Crabs & 5 & 7 & 7 & 6 & 10 & 8 & 15 \\
\hline Total markets & 74 & 82 & 110 & 158 & 145 & 162 & 167 \\
\hline
\end{tabular}

Source: Department of Customs, Sri Lanka, 1990-2006

International seafood market regulations ensure that Sri Lanka has to compete with other countries to market its products. In this regard, there is a need to up grade the safety and quality measures used in the fish processing industry to meet global demand. The introduction of HACCP based regulations has changed drastically the way equivalence between countries is assessed and how compliance of fish and fishery products to safety regulations is determined in international trade (Lupin, 1999). These new requirements have not been well researched within the fishing industry economics of Sri Lanka. Therefore this study will help to provide a better insight on the present situation of Sri Lankan seafood exports. 


\section{Objectives of the study}

1. To identify the requirement food safety measures based on HACCP using the seafood processing businesses in Sri Lanka

2. To find out the impact of HACCP, level of sanitation, labor, capital and traceability on export penetration of the seafood export business

3. To draw implications about the impact of food safety regulations (HACCP) on corporate success of seafood processors

\section{Theoretical Approach}

The conceptual framework was based on adoption of quality control measures (HACCP system) and its impact on export market performance. The theoretical approach is based on Zaibet's (2001) study on compliance to HACCP in Oman fish processing. Current study utilizes the same theoretical approach employed by Zaibet (2001).

A hypothesis was constructed based on the findings of previous research and literature.

HO = Level of HACCP, level of sanitation, number of employees occupied, amount of capital invested and traceability of the products have a negative impact on export penetration of a seafood processing company.

$\mathrm{Hl}=$ Level of HACCP, level of sanitation, number of employees occupied, amount of capital invested and traceability of the products have a positive impact on export penetration of a seafood processing company.

Assume that the various kinds of processed seafood products as one category and the required food safety and quality measures are similar for all processed seafood products. The empirical model to be estimated for the EPI (Export Penetration Index) is as follows;

$$
\text { EPI = f (HACCP, Sanitation, Labor, Capital, Traceability) }
$$

HACCP was defined by a number of binary variables that show the commitment of the firm to the implementation of HACCP. These variables include documentation, training, records, procedures, sanitation conditions and so forth. In this study we used 4 levels of HACCP, such as HACCP level 0 - a seafood processing company that has made a negative response to adopt the HACCP system; HACCP level 1 - a seafood processing company that has made a positive response to adopt the HACCP system; HACCP level 2 - a seafood processing company that has participated in HACCP training programmes conducted by the "Quality Control Unit" and 
implemented the HACCP documentation and HACCP level 3 - a seafood processing company that has employed a HACCP consultant and has fully implemented the HACCP system. SANI 1 and SANI 2 were the two levels of sanitation use for the analysis. The layout of a seafood processing company which needed to make minor modifications (eg. changing floor tiles and equipment at receiving point, changing the interior lighting system, color washing the walls, etc.) to match with HACCP requirements was considered as a SANI 1 category. SANI 2 represents the seafood processing companies required to make major modifications (such as changing the water supply system, constructing separate dressing room factory workers, changing the ventilators and drains, etc.) to their layout to suit with the HACCP system. The definition of traceability, defined by the Codex Committee on Food Import and Export Inspection and Certification Systems (CCFICS) was used for this study. CCFICS describes traceability as the ability to identify a food (product identification), how it was changed (if appropriate), where it came from and where it was sent (one step backward and one step forward) (product information), and the links between product identification and product information, while also noting that the applicability of these elements will depend on the objectives being pursued by the individual texts (CCFICS, 2002).

\section{Materials and methods}

Primary data was collected from the Western and Northwestern provinces of Sri Lanka, in March - April 2004, through structured questionnaires together with in depth interviews and field observations. The study sample consisted of 50 randomly selected marine product processing plants (although $26 \mathrm{EU}$ approved establishments were purposely included in the sample) with some established inside the export processing zones. The sample represented $12 \%$ of the total establishments. A written questionnaire consisting of two parts was developed especially for this study. The first part of the questionnaire consisted of 15 questions related to seafood businesses (such as product types, production capacity, cold storage, distribution system, markets, employees, product promotion and research and development. Part two included 45 questions related to the implementation of the HACCP, status of the record keeping, HACCP training, personal hygiene practices and procedures, buildings, ground and environmental hygiene, equipment cleaning, sanitation, presume of HACCP requisite programmes and specific questions related to steps in the flow of food (purchasing, receiving, storage, production and service) were also included.

These data were used to derive an export penetration index as defined by equation (1). A scale variable ( $0-3)$ of the status of HACCP was calculated by adding three binary variables ( 1 - if the company has responded positively 
and 0 - otherwise), participation in HACCP training, implementation of HACCP documentation and employment of an HACCP consultant. Labor was approximated by the number of employees. Labor could be used as a proxy for the size of the company. The size has been found to be both positively and negatively associated with export performance (Baldauf et al., 2000). Capital was defined by investments in freezing and storage capacity together with processing plant space. The variable sanitation was defined by dummy variables: SANI 1 was used if the plant required minor modification to meet EU sanitation requirement and 0 otherwise; SANI 2 was defined in a similar way when the company required major modifications and reconstruction. Published sources of the Ministry of Fisheries and Aquatic Resources, Department of Customs and Quality control unit were used as secondary data for Sri Lanka. Field observations of South Asian seafood exporting countries and published sources of the related governmental and non governmental organizations of the seafood exporting industry in India, Bangladesh, Pakistan and Maldives were used to determine the present status of the safety measures.

\section{Results and Discussion}

\section{HACCP procedures in Sri Lanka}

Export of seafood products from Sri Lanka begun in the early 1980s with the expansion of prawn farming. After two decades it expanded to a diversified product range to destinations all over the world. Processing establishments are mainly owned and handled by the private sector, while quality assurance is handled by the government sector. Quality control of fish product exports commenced with the enactment of the fish processing establishment regulations; fish products (export) regulations and amendment to the fish products (export) regulations (Government of Sri Lanka, 2000). A fishery product quality control unit of the Ministry of Fisheries and Aquatic resources was established in January 1999, in response to requirements laid down by the EU with regard to import of fishery products from Sri Lanka. The EU considered being the main market for Sri Lankan seafood exports and it is worthy to follow EU regulations. The main objective of the unit is to ensure a high standard of quality and safety of exported products for the international market (Amarasinghe, 2003). The basic requirement for the HACCP implementation in Sri Lanka began with good manufacturing practices (GMP) and follows international standards. Prior to designing a HACCP plan, the food premises are expected to be able to demonstrate ongoing compliance with GMP, regulatory and market access requirements. Confirmation of effective prerequisites means that the HACCP team can focus on a genuine design of a HACCP plan for the selected seafood product. 
If the processing plant has a variety of seafood products, each and every product should have a separate HACCP plan. Only 7\% of the Sri Lankan seafood processing firms adopted HACCP and the ISO 9000 based regulatory system. The majority of the companies (93\%) maintain their own sanitary standards which are dependent on the buyer's requirements. On the other hand HACCP based companies are responsible for the major portion of Sri Lankan seafood exports. HACCP based seafood products mainly target to higher value export markets, such as the EU, the USA and Japan. Table 3 presents the percentage of seafood exports to main markets and compliance on the steps of HACCP procedures. However, local market conditions are still far from international standards.

Table 3: Exports to main markets (\%) and level of HACCP compliance

\begin{tabular}{|c|c|c|c|c|c|c|c|c|c|c|c|}
\hline \multirow{2}{*}{ Plant } & \multirow{2}{*}{ 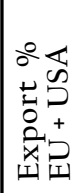 } & \multirow{2}{*}{ 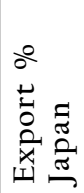 } & \multirow{2}{*}{ 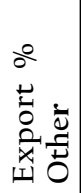 } & \multicolumn{8}{|c|}{ HACCP Plan (\%) } \\
\hline & & & & 1 & 2 & 3 & 4 & 5 & 6 & 7 & 8 \\
\hline $\begin{array}{c}\text { EU } \\
\text { approved } \\
\text { firms }\end{array}$ & 85 & 15 & - & 100 & 100 & 60 & 40 & 100 & - & - & - \\
\hline $\begin{array}{l}\text { Non EU } \\
\text { approved } \\
\text { firms }\end{array}$ & - & 42 & 58 & 48 & 40 & 5 & 10 & 8 & 35 & 44 & 56 \\
\hline
\end{tabular}

Source: field survey, April-March, 2004.

1 - Interest; 2 - Documentation; 3 - In-house training; 4 - Outside training;

5 - Consultant; 6 - Underway;

7 - Sanitation level 1(Minor modifications to meet sanitation requirements);

8 - Sanitation level 2 (Major modifications to meet sanitation requirements)

Restructuring of Sri Lanka's fishing industry in the early 2000, has mainly been targeted to boost exports. It has further led to the introduction of new technology. It has also resulted in the changing attitudes of fishermen and fish distributors regarding quality standards and better handling procedures of fish, leading to less spoilage and wastage of landed fish and better quality fish available at the local market. Processors who are producing for supermarket chains in Europe have to follow the proprietary quality management systems 
and food safety regulations other than the internationally reputed quality assurance measures. For a example, Tuna and prawn products for the Sainsbury's and Tesco retailer chains in the UK should be processed under the buyers special set of quality requirements based on the ISO set of standards. Furthermore, Japanese super market chains prefer to buy whole fish in its freshest form for sushi and sashimi and the exporters have to maintain the temperature and Histamine growth.

\section{HACCP and South Asian seafood processors}

Common features of the south Asian region include a huge domestic market for fish and fishery products, poor safety and quality systems. Cultural and religious believes make fish a main source of protein among people of the Maldives (fish $\backslash$ animal protein ratio was $81.4 \%$ ) and Sri Lanka (fish $\backslash$ animal protein ratio was 52.3\%) compared to India, Pakistan and Bangladesh (National Disaster Management centre, 2005). Furthermore, domestic supply is not enough to fulfill the local demand in India where the (per capita supply of fish in 2001 was $4.9 \mathrm{Kg}$ ) (National Disaster Management centre, 2005). The seafood exporters of the South Asian region face a major challenge because most trade is with the EU and the USA with stringent quality and food safety standards. The following institutions are acting as competent authorities in each country and handle the food safety measures: Marine Products Export Development Authority and Export Inspection Council for India; Quality Control Unit of the Ministry of Fisheries and Aquatic Resources for Sri Lanka; Marine Fisheries Department (MFD) for Pakistan and Bangladesh Standards and Testing Institution (BSTI) for Bangladesh. There is no national standards organization in Maldives to handle the food safety and quality measures.

Both India and Sri Lanka are considered as EU list 1 country for seafood exports. The EU list 1 countries are known as harmonized or approved countries for the export of seafood into the European Union. The legislation requirements of these countries are at least equivalent to those governing the EU domestic production, and that have been audited by an EU inspection team with the competent authority satisfy EU requirements. A specific decision has been adopted for each of these countries fixing specific import conditions, including the official recognition of the competent authority, a specific model of health certificate and a list of approved establishments. Barely 5\% of India's seafood exports are in processed form (Kulkarni, 2005). Most exports are in the form of frozen fish and the Indian brands are not common in main markets (Kulkarni, 2005). Generally, more than $60 \%$ of India's exports to South East Asia are re-exported after processing. ISO 9000 (1994 and 2000 versions), HACCP and EU approval are the widely spread quality standards in India. HACCP has become a 
mandatory requirement for the seafood processors to the main markets of the EU, and the USA. But processors have little interest in upgrading their systems. Food safety issues, mainly the HACCP and export regulations are the concerns of the exporters. Furthermore, rest of the chain is completely unaware of which and these regulations leads to heavy post-harvest losses.

In Bangladesh, BSTI has acquired experience in setting national standards and implementing through their BSTI mark scheme. However, the standards formulating system and product certification scheme has not kept pace with modern developments in the standardization and conformity assessment systems. However, BSTI standards cannot be harmonized with international standards. The EU and the USA banning of Bangladesh shrimp (antibiotic residues) caused huge losses to the industry's people.

In Pakistan, MFD, is a federal government organization for quality standards. Twenty eight seafood processors are currently involved in export to the EU. An EU concerns on banning of Pakistan seafood exports in 2005 alarmed that Pakistan would lose its largest seafood market. A Self imposed ban on seafood exports for 6 months has allowed exporters and government authorities to upgrade the system. The EU ban on Pakistan seafood was due to the poor seafood quality, safety standards and dingy conditions of Pakistani harbors and auction houses. Furthermore, the lack of hygienic conditions starting with the fishing boats, through the landing sites and the auction halls and into the processing plant where the main issues. Pakistani seafood exporters have to get a clearance certificate from MFD and the MFD inspectors after inspecting the quality of seafood and safety measures before exportation.

The Maldives is the one of the wealthiest among the least developed countries and their economy mainly depends on tourism and tuna fisheries. The main export markets are the EU and Sri Lanka. But, with the stringent food safety regulations of the EU, Maldivian seafood exporters are facing major challenges. The Maldives has no organized system of ensuring food safety standards for its fishing industry and assist companies to obtain third party certification for easy access to global markets. Furthermore, lack of training programmes for the employees in the processing industry is another inhibiting factor in exports. There is a possibility to up grade the wellequipped and properly managed test laboratory of the state-owned tuna processing factory to a certification centre for tuna. Maldivian exporters follow two main strategies to overcome this barrier, such as obtaining health certificates from Sri Lanka, and exporting directly to Sri Lanka for re-export to EU.

The South Asian region is lacking the provision of quality ice, cold storage, clean water, and hygienic physical conditions due to poor on-site management, 
absence of performance incentives for the authorities and monopolistic control by the male holders and the local government officials. It is important to improve the conditions at landing sites by providing clean water and proper beach landing centers to avoid post-harvest losses. Moreover, post-harvest losses can be reduced with the introduction of common practices for fishermen such as on board hygiene practices, and handling and storing methods. Small scale processors in the South Asian region are facing immense competition from huge global counterparts operating in their territories; upgrading their systems to match with HACCP is a big burden to them. For an example, the minimum cost of a EU certified, large scale plant in India is about 80 million Rupees (1 US $\$=49.15$ Indian Rupees) and about 190 million Rupees ( 1 US $\$=113.92$ LKR) in Sri Lanka. Furthermore, the EU standard of "zero tolerance" policy regarding antibiotic residue, strict regulations on micro-organisms and specific substances present in final product as well as environment aspects, for instance, packing, are critical to South Asian exporters. The following are common reasons to the South Asian region that were identified during the study regarding the reluctance to comply with the HACCP based food safety system.

- Large domestic market that doesn't require stringent food safety measures (often $2^{\text {nd }}$ grade raw materials are being processed for the internal market)

- Producers ' familiarity with the old inspection system based on the Physical Hygiene Inspectors in the area

- Fears that new food safety standards would bring additional costs to the production process

- Fears that a more stringent HACCP system will make the producers liable to receive banning, punishments or penalties

- Poor or limited knowledge of the HACCP system among managers, quality assurance personnel, supervisors and factory workers of the seafood processing plants

- No guarantee of benefits such as increase exports or demand or high returns

Tables 4 and 5 explain the results of the statistical analysis. The model summary shows that the adjusted $\mathrm{R}^{2}$ is $0.716(72 \%)$, and about $72 \%$ of the export penetration was explained by the considered dependent variables. Results also revealed that the model really matches with the hypothesis of the paper. Labor (number of employees of the processing plant) has very little impact on export performance, while SANI 2 (Sanitation level 2 = processing plant which has to do major modification) has a negative impact on export performance. Results explain that EPI is decreasing with the increasing level of SANI 2. Processing plants with poor sanitation levels are 
far from the international market requirements and they have to upgrade their standards to enter the export market. Level of HACCP, capital, and SANI 1 have little positive impact on a company's export performance. All EU approved companies have their own HACCP plan and have reached HACCP level 3 in the model. Companies processing for higher value markets were strengthened by their own HACCP plan for each and every product. Compared to other variables, traceability has the highest Beta value and mode, suggesting that impact of traceability for the export performance is quite high. All companies producing for the EU and USA market have their own traceability system and this is a special requirement for prawn and shrimp processors. Furthermore, the majority of the small (plants with $>50$ employees or minimum investment of 4 million rupees) and medium (plants with 50-200 employees and minimum investment of 10 million rupees) scale processors were not using the traceability system. Table 6 explains the implementation of the HACCP based food safety measures in the seafood processing industry in Sri Lanka.

Table 4: Results of the OLS model

\begin{tabular}{|c|c|c|c|}
\hline Variable & \multicolumn{3}{|c|}{ OLS model } \\
\hline Intercept & 0.377 & 5.504 & 0.000 \\
\hline HACCP & 0.288 & 1.268 & 0.212 \\
\hline Labor & 0.054 & 0.293 & 0.771 \\
\hline Capital & 0.213 & 0.990 & 0.328 \\
\hline SANI 1 & 0.201 & 1.605 & 0.116 \\
\hline SANI 2 & -0.001 & -0.012 & 0.990 \\
\hline Traceability & 0.488 & 1.982 & 0.054 \\
\hline
\end{tabular}

Table 5: Model Summary ${ }^{\mathrm{b}}$

\begin{tabular}{|c|c|c|c|c|}
\hline Model & $\mathrm{R}$ & $\mathrm{R}^{2}$ & Adjusted $\mathrm{R}^{2}$ & $\begin{array}{c}\text { Std. Error of } \\
\text { the estimate }\end{array}$ \\
\hline 1 & $0.867^{\mathrm{a}}$ & 0.752 & 0.716 & 0.11554 \\
\hline
\end{tabular}

a - Predictors: (Constant), TRACE, Labor, SANI 1, SANI 2, Capital, HACCP

b- Dependent variable: EPI 
Table 6: Present status of HACCP based regulatory system in Sri Lanka

\begin{tabular}{|l|c|c|}
\hline \multicolumn{1}{|c|}{ Status } & Number & Percentage \\
\hline Completely HACCP adopted companies & 26 & 7 \\
\hline Companies on the process of HACCP & 48 & 12 \\
\hline Non HACCP adopted companies & 322 & 81 \\
\hline
\end{tabular}

Source: Field survey March-April, 2004.

The level of capital investment of a company has an indirect relationship with HACCP, sanitation and traceability. Companies that invest more have better chances to improve their export performance. Lack of financial resources and limited access to financial capital were the main limiting factor for the industry's success and some companies with foreign investor collaboration had a better chance to improve their quality assurance systems.

Companies with a high level of HACCP compliance (maximum level 3 in model), have invested more on employee training (in-house, local and foreign training), consultants (quality controllers, expert consultations from outside) and documentation. On the other hand, companies with a low level of HACCP compliance (zero or one in model) have not yet invested in development of their own quality assurance system. Especially, companies who are catering to the Asian markets such as China, South Korea, Taiwan, Singapore and HongKong, have low interest in developing their own quality assurance systems. Of the sample, some companies would only require minor modifications to the plant (the plant layout is acceptable) to reach the internationally required standards. These plants need to pay more attentionon their level of sanitation and should improve to fulfill customer needs.

Companies need major modifications when their general layout is unacceptable, and this affects the whole process. Of the sample, plants belonging to this category experienced poor export performance. Moreover, more than 50\% of their product is exported to Asian markets mainly Hong Kong, Singapore, South Korea and China. Table 7 describes the correlations among independent variables. The findings of this study demonstrated that the staff of the seafood processing companies (except EU approved companies) has a lack of food safety knowledge, and the owners have a negative attitude towards up-grading the food safety measures of their plants. The problems of implementing HACCP in Sri Lankan seafood processing have been namely, a low level of food hygiene management training for processors 
and employees of processing plants, high staff turnover rate, lack of motivation, lack of financial resources, inadequate equipment, physical conditions of the facility, low level of state intervention and the impact of hot, humid weather.

Table 7: Pearson correlation matrix and level of significance

\begin{tabular}{|l|c|c|c|c|}
\hline & EPI & HACCP & Labor & Capital \\
\hline EPI & & & & \\
\hline HACCP & $0.824^{* *}$ & & & \\
\hline Labor & $0.368^{*}$ & 0.228 & & \\
\hline Capital & $0.609^{* *}$ & $0.510^{* *}$ & $0.856^{* *}$ & \\
\hline SANI 1 & -0.089 & -0.043 & -0.207 & -0.320 \\
\hline SANI 2 & $-0.587^{* *}$ & $-0.707^{* *}$ & -0.130 & -0.305 \\
\hline Traceability & $0.785^{* *}$ & $0.867^{* *}$ & 0.221 & $0.547^{* *}$ \\
\hline
\end{tabular}

\footnotetext{
* - Significant at 0.001 level (1 - tailed)

* - Significant at 0.005 level $(1-$ tailed $)$
}

\section{Conclusion}

The concluding remarks start with the fact that, the HACCP system is important for maintaining food safety in seafood exports industry, yet it seems that the HACCP system is not implemented widely in Sri Lanka. Strict safety measures are maintained by the quality control unit and the cooperation of the seafood processors there are many issues imposing risk on seafood safety due to commercial production, emergence of longer and more complex food chains, exports to higher value markets, growing international trade and tourism. The problems of implementing HACCP in Sri Lankan seafood processing were: the low level of food hygiene management training; the quality control unit's lack of financial, physical and human resources for organizing training; a low level of government involvement; poor participation of the private sector, and lack of motivation of the seafood processors. Furthermore, one of the major problems is that the majority of the seafood processors often lack interest and have negative attitude toward food safety programmes in Sri Lanka. Some establishments processing for specified retail chains in Europe follow a unique total quality management system based on HACCP principles, adopting the buyer's requirements. 
Even if processing establishments are rather diverse in size of operation, product type or destination, the implemented quality assurance systems show essentially common characteristics, although at different levels. The functions, definitions, responsibilities, and human resources involved in quality management are common characteristics for the seafood processors to higher value markets.

The study tests empirically, the relationship between HACCP and success in export markets by constructing an index of export penetration. The level of HACCP compliance, number of employees, capital, sanitation (SANI 1) and traceability were positively correlated to the export penetration index, and these factors are responsible for $72 \%$ on the EPI. Only sanitation (SANI 2) was negatively correlated to the EPI. Results supported the hypothesis as outlined. Findings also highlighted that establishments processing for higher value markets try to maintain their quality for further expansion. Meantime non-HACCP adopted companies also have a strong interest in implementing the HACCP system to maintain or regain their competitive position in higher value markets. Most companies that have adopted the HACCP system have foreign collaboration and technical assistance to upgrade their system. In order for locally based seafood processors to upgrade, government assistance is required to improve their infrastructure, e.g. their test laboratories (in terms of equipment), technical skill development of quality management staff and directions for a master-plan. In contrast, some establishments that are mainly targeting the Asian markets (including the Japanese market) do not follow an HACCP based quality management system and have no interest in one either. But among them some companies achieve better returns than HACCP adopted companies. There is an urgent need to provide substantial food safety training to all employees engaged in seafood processing and continuous monitoring of training programmes.

In general, Sri Lankan seafood processors have to adopt an HACCP-based regulatory system to overcome the barriers in international trade, such asstricter regulations and competitor rivalry (especially with South Asian neighbors). The capital requirement to upgrade the establishment to an HACCP level depends on the modifications needed to meet international standards. This study identified two categories: establishments that need minor modifications and those which need major modifications. Companies need major modifications to the system to achieve an HACCP controlled production system, and have to make master plan in order to upgrade there facilities. But initial involvement costs are very high and seafood processors in Sri Lanka are unable to bear the cost without the government assistance. There it acts as a non tariff barrier for the capital deficit nation. This study also reveals that quality control measures for the domestic market are very 
poor and similar to that of most developing societies in Asia. Finally, HACCP opens up new avenues in higher value export markets while assuring the Sri Lankan position in the international market. In the meantime, it paves the way for the expansion of export market boundaries. Findings highlighted that the companies adapting the HACCP system enjoy better returns within wider choices of expansion. Upgrading of the non-HACCP adopting companies is a challenge to both their owners and the government.

India, Pakistan and Sri Lanka have a strong position in implementing food safety measures followed by the EU standards. Bangladesh, the Maldives, Bhutan and Nepal are making progress in reaching HACCP compliance. The legal and institutional structure to manage the food safety measures have not yet been fully developed to international standards in many South Asian nations. The development of national standards for food safety and quality assurance will not only help in increasing exports, but also in upgrading the quality of seafood products in their local market. The majority of the trade-limiting factors for seafood export industry in South Asia relate to unstable economic conditions, poor infrastructure and lagging skills. The South Asian seafood exporting industry has to follow a bottom up approach for food safety and hygiene. The members of the bottom level of the seafood supply chain have little knowledge on food safety measures. Filling the knowledge gap between fishers and exporters on food safety measures is very important to the South Asian region.

\section{References}

Amarasinghe, O. (2003) International trade in fish and fish products and food security in Sri Lanka, An FAO study. pp. 73-75.

Baldauf, D.W.C and Wagner, U. (2000) Examining determinants of export performance in small open economies. Journal of World Business.v. 35(1), pp. 6l-75.

Cato, J.C. (1998) Seafood safety; Economics of HACCP programmes, fish utilization and marketing service, fishery Industries Division, FAO fisheries Department, Rome, Italy.

Central Bank of Sri Lanka, (2003) Annual Report, Central Bank of Sri Lanka Colombo, pp. 296-302.

Codex Committee on Food Import and Export Inspection and Certification systems( CCFICS), (2002) Traceability, Concept elements and definitions, Codex Committee on Food Import and Export Inspection and Certification systems (CCFICS), 1 lth $^{\text {S }}$ Session, Adelaide, Australia, 2-6 Decembe 2002, Agenda Item 7, CX/FICS/02//11/7 paragraph 7. 
Codron, J.M., Sterns, J.A. and Reardon, T. (2000) Consumer preferences, experience and credence issues and their strategic implications for French and US fresh produce sectors. International Food and Agribusiness Management Forum, June, Chicago, USA.

Department of Customs Sri Lanka, (1990-2006) Annual customs records, Department of Sri Lanka Customs, Colombo, Sri Lanka.

Export Development Board, (1998-2003) Annual Reports. Export development Board, Colombo, Sri Lanka.

Government of Sri Lanka, (2000) Gazette Notification of the $6^{\text {th }}$ April 1998, No.1126/20, Government of Sri Lanka.

Kulkarni, P. (2005) The Marine Seafood export supply chain in India: Current State and Influence of Import Requirements, Trade Knowledged Network Progamme, www.sdpi.org/tkn/cuts, Accessed September $11^{\text {th }}$ 2005.

Lupin, H.M. (1999) Producing to achieve HACCP compliance of fishery and aquaculture products for export, Fishery Industries Division, FAO/ DANIDA Training programme, Rome, Italy. www. pao.org. Accessed $15^{\text {th }}$ May 2005.

Martins, J.O. (1993) Export behavior with differentiated products: exports of Korea, Taiwan and Japan to the US domestic market. In: M.G. Dagenais and P.A.Muet, Ed. International trade modeling, Champan and Itall, New York, pp. 37-52.

National Dissaster Management Centre, (2005) TSunami 2004, National Disaster Relief Services Centre, Sr Lanka, www. udmc.gov.lk, Accessed 16 ${ }^{\text {th }}$ March 2005.

Sanchez, A.H. (2004) Fresh fruit producer's organizations in France: The impact of HACCP and ISO 9000 standards adoption, 44 th annual meeting of the Gesellschaft fur wirtschafts - and Sozialwissenschaften des Landbaues, Faculty of Agriculture and Horticulture, Humboldt Universitat Berlin, www. food quality schemes. jvc. ec. europa. eu, Accessed 20 $0^{\text {th }}$ June 2005.

Zaibet, L. (2001) Compliance to HACCP and competitiveness of Oman fish processing. The International Food and Agribusiness Managent Review, v. 3, pp. 311-32l. 
1 